УДК 378.14

\title{
МЕТОДОЛОГІЯ В СИСТЕМІ ОСВІТИ
}

\author{
Леонід Гаврилович Трусей
}

Викладач Харківського національного університету повітряних сил

В доповіді розглянуті онтологічні і методологічні проблеми сучасної освіти, його недоліки. Запропоновані шляхи створення концептуально нової системи освіти.

Ключові слова: система, освіта, онтологія, методологія, людина.

Проблеми освіти носять онтологічний характер тому, що ми не цілком розуміємо складнощі сучасного світу і ролі в нім людини. Змінилася і продовжує мінятися усе середовище існування людини і темпи цих змін усі збільшуються. Перехід від епохи варварства до епохи цивілізації [1], який ми зараз переживаємо, потребує людей абсолютно іншого типу, наділених абсолютно іншим мисленням, працюючих в інших індустріях і таких, що мають інші набори навичок.

Особливої актуальності набуває проблема досягнення людини i його природи в цей історичний період, коли повинен практично вирішуватися питання «Бути або не бути... людству»? «...Ми маємо справу — завжди і передусім — 3 людським феноменом, тобто з нашим реальним життям, коли думаємо про неї не в термінах існуючих теорій i інституцій (що мають свої теорії), а в термінах власного життя і в контексті його проблем.» — писав М. К. Мамардашвілі [2].

Початок нового століття і тисячоліття приносить чітке розуміння і усвідомлення головного завдання науки і освіти : дослідження і становлення внутрішнього духовного світу людини. Без такого досягнення Універсуму і людини, здійснення практичних результативних дій в цьому напрямі навряд чи можна знайти реальні шляхи виходу з глобальної кризи сучасності, що поглиблюється. Одухотворення, олюднення дійсності сьогодні стає рівнозначне виживанню і порятунку людства.

Перед ученими і усіма землянами постало фундаментально-рятівне питання: чи готові ми «прийняти єдність науки і духовності» [3]. 
Із сказаного витікає розуміння того, що вихід-виживання вимагає кардинально якісної зміни моральності і якостей кожної людини. Усвідомлення цього цілком можливо досягнути, як один 3 напрямів, створенням абсолютно нової системи освіти. Базовий перехід (якого не відбулося) до нової системи освіти повинен грунтуватися на ситуаційному аналізі сучасної освіти. Його повною мірою не озвучили досі. В зв'язку з цим основні тези такі:

накопичена величезна кількість інформації у кожній галузі знань, яку в принципі неможливо дати учням за відведений період для освіти;

- встановлено (зокрема вченими Японії), що інформація, ідеї, технології і тому подібне застарівають кожні 5-10 років;

- моральне становлення підростаючого покоління не відповідає сучасним складнощам земного буття людини [4];

- ускладнення усіх сторін життя людини зажадало нового рівня вимог до випускників — це поліфункціональність, висока професійна підготовка ( напр., випускник ПТУ прирівнюється до інженера першої половини XX століття). Особливо високі вимоги до моральних і психічних якостей і тому подібне. Учити усіх всьому [5];

- одна з характеристик сучасності полягає в тому, що нові технології .вже витіснили з сільського господарства і промисловості більше 2/3 зайнятих працівників і в XXI столітті цей процес ще більше посилюватиметься. Чисельність працюючих людей впаде на порядок.

Вже на підставі приведеного аналізу можна зробити наступні висновки:

Висновок 1. Фактично вживана в сучасній системі освіти цитатнодогматична (фактологічна) педагогіка віджила свій вік і не дозволяє готувати молоде покоління до життя.

Висновок 2. Створюючи нову (не реформуючи стару - вона мертва) систему освіти треба будувати ії зовсім на принципово іншій педагогіці - педагогіці методологічній. Суть іiі полягає в першу чергу в дачі методологічних знань - знань як інструментарію отримання нових (будь-яких) знань. По нашому розумінні, визначення методології таке: методологія - це система принципів і способів (методів) організації теоретичної і практичної діяльності людей.

Висновок 3. Сьогодні роль Прикладної Онтології, інших гуманітарних, природничих наук і передусім філософії про перегляд картини світу і місця в нім людини стоїть як ніколи гостро. Макс Шеетер [6], 
Гроф К., Гроф С. [7], Тейяр де Шарден[8], Рассел Б. [9], Фукуяма Ф. [10] і інші писали про феномен людини і ії місце в реалізації майбутнього як самої людини, так і людства в цілому. Розвиток науки в цьому напрямку повинен грунтуватися на новому антропологічному принципі - розумовій діяльності людини. Йдеться про освіту яка грунтується на «пробудженні свідомості», як радив Лев Толстой [11]. Діяльність людини в XXI столітті — це головне завдання як науки, так і кожної людини як земного мешканця.

Висновок 4. Групою учених розробляється на інших концептуальних і програмних принципах система духовно-інтелектуального виховання і освіти (ДИВО-21) яка покликана започаткувати всі досягнення людства в освітній сфері і відповідає вимогам і реаліям ХХІ століття.

\section{Література}

1. Бабич В.П., Могилко В.А., Онегина В.М. Прикладная онтология. Харьков.: Мадрид, 2013.

2. Мамардашвили М.К. Из лекций по социальной философии. Социологический журнал, № 3, 1994.

3. Талбот А. Голографическая вселенная. М.: Изд. София, 2005.

4. Вернадский В.И. О русской интеллигенции и образовании. Открытия и судьбы. М., 1993.

5. Каменский Я.А. Великая дидактика (Избранные главьі). Зл. версия по изд.: Педагог, наследие, М.: Педагогика, 1989.

6. Шелер М. Формы знання и образование. Человек. Вьш. 4. М., 1992.

7. Гроф К., Гроф С. Духовний кризис: Когда преобразование личности становится кризисом. М.: ООО «Издательство АСТ». 2003.

8. Тейяр де Шарден П. Феномен человека: Сб. очерков и зссе: Пер. с фр. М.: ООО «Издательство АСТ», 2002.

9. Рассел Б. Избранные труды. Н.: Сиб. университетское изд. 2009.

10. Фукуяма Ф. Доверие: социальньїе добродетели и путь к процветанию. Перевод с английского Д. Павловой, В. Кирющенко, М. Колопотина. М.: ООО «Издательство АСТ»: ЗАО НПП «Ермак», 2004.

11. Толстой Л. Н. О народном образовании. Собр. соч. в 22 т. Т. 16. М., Худ; лит. 1983. 